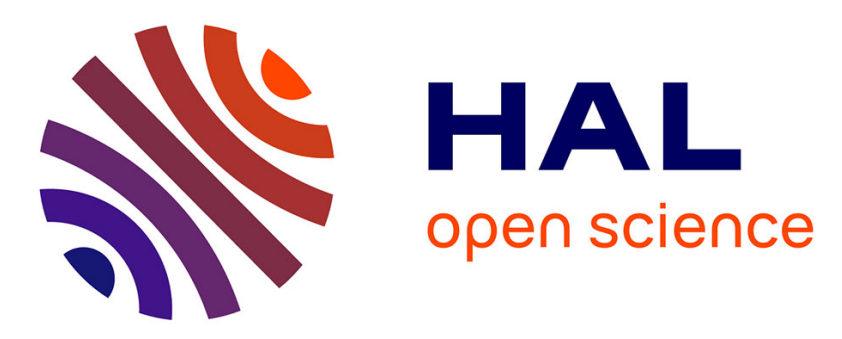

\title{
Bilateral negotiation of a meeting point in a maze: Demonstration
}

Maxime Morge, Jean-Christophe Routier, Fabien Delecroix

\section{To cite this version:}

Maxime Morge, Jean-Christophe Routier, Fabien Delecroix. Bilateral negotiation of a meeting point in a maze: Demonstration. International Conference on Practical Applications of Agents and MultiAgent Systems (PAAMS), Jun 2014, Salamanca, Spain. Springer, 8473, pp.327-330, 2014. hal01058684

\section{HAL Id: hal-01058684 \\ https://hal.inria.fr/hal-01058684}

Submitted on 27 Aug 2014

HAL is a multi-disciplinary open access archive for the deposit and dissemination of scientific research documents, whether they are published or not. The documents may come from teaching and research institutions in France or abroad, or from public or private research centers.
L'archive ouverte pluridisciplinaire HAL, est destinée au dépôt et à la diffusion de documents scientifiques de niveau recherche, publiés ou non, émanant des établissements d'enseignement et de recherche français ou étrangers, des laboratoires publics ou privés. 


\title{
Bilateral Negotiation of a Meeting Point in a Maze: Demonstration
}

\author{
Fabien Delecroix, Maxime Morge, and Jean-Christophe Routier \\ Laboratoire d'Informatique Fondamentale de Lille \\ Université Lille 1 \\ Cité Scientifique- F-59655 Villeneuve d'Ascq \\ \{fabien.delecroix, maxime.morge, jean-christophe.routier\}@lifl.fr
}

\begin{abstract}
Negotiation between agents aims at reaching an agreement in which the conflicting interests of agents are accommodated. In this demonstration, we present a concrete negotiation scenario where two agents are situated in a maze and the negotiation outcome is a cell where they will meet. Their individual preferences match with a minimal distance computed from their partial knowledge of the environment. We illustrate a bargaining protocol which allows agents to submit several proposals at the same round and a negotiation strategy which consists in starting from the best deal for the agent and then concedes. The path between the agents emerges from the repeated negotiations.
\end{abstract}

\section{Introduction}

Multiagents systems (MAS) is a paradigm to analyze, to design and to implement systems made of autonomous entities interacting each other. These systems are characterized by oppositions. These conflicts exist since agents have a local perception of the environment and/or their own goals. In a MAS, the agents, even if they are self-interested, must collaborate to reach their goals. Negotiation is a form of interaction to reach a mutual agreement. This agreement can be a resource allocation [1-6], a 2-side matching [7] or a collective decision [8]. The goals of the agents are conflicting since they cannot be fully satisfied at the same time. In this perspective, negotiation is a distributed search in a potential agreements space [9].

Many complex negotiation environments can be considered: multi-party negotiation (with more than two agents), multi-issue negotiation (the potential agreements space is multi-dimensional), argumentation-based negotiation (offer are attacked/defended), assumptions over the agents' preferences (reservation value, discount factor, deadline, etc.). Based on the principle of parsimony, we study proposal-based bilateral single-issue negotiation in a companion paper [10]. We illustrate here our negotiation game in a concrete scenario where two agents are situated in a maze and the negotiation outcome is a cell where they will meet. 


\section{Main Purpose}

Tab. 2] situates our negotiation environment [10] wrt related works.

Many different negotiation environments have been studied in the literature:

- the object of negotiation can be single-issue or multi-issue, with discrete or continuous issues;

- the agents' preferences (2 or more) can be captured by preference relations (denoted $\succsim)$ or utility functions (denoted $u$ );

- the negotiation protocol can be symmetric or asymmetric, simultaneous or successive, continuous or discrete, with or without deadline;

- the knowledge of agents about the opponents can be perfect or imperfect.

We distinguish two approaches to design multiagents negotiation. In the gametheoretical approach, the negotiation environment is restricted to formally validate the properties of the outcome (optimality) and of the process (stability, computational complexity, distribution, etc.). In the heuristic-based approach the negotiation environment is realistic but the properties are empirically evaluated. The imperfect information is the major difficulty for the first approach. However, since we adopt the heuristic-based approach, we think this assumption is crucial for practical application.

Table 1. Analysis grid of the literature according to the negotiation environment.

\begin{tabular}{l|l|l|l|l|l|l} 
& $\begin{array}{l}\text { Nb } \\
\text { agents }\end{array}$ & Object & Pref. & Protocol & Deadline & Information \\
\hline$[1]$ & 2 & Single continuous & $u$ & $\begin{array}{l}\text { symmetric si- } \\
\text { multaneous }\end{array}$ & no & perfect \\
$-[2]$ & 2 & single continuous & $u$ & $\begin{array}{l}\text { asymmetric } \\
\text { successive }\end{array}$ & no & perfect \\
$-[3]$ & 2 & multi continuous & $u$ & $\begin{array}{l}\text { asymmetric } \\
\text { successive }\end{array}$ & yes & $\begin{array}{l}\text { perfect } \\
\text { imperfect }\end{array}$ \\
\hline$[\overline{4}]$ & 2 & single continuous & $u$ & $\begin{array}{l}\text { asymmetric } \\
\text { successive }\end{array}$ & yes & imperfect \\
$-[5]$ & 2 & single continuous & $u$ & $\begin{array}{l}\text { asymmetric } \\
\text { continuous }\end{array}$ & yes & imperfect \\
$-[\overline{6}]$ & $\mathrm{n}$ & $\begin{array}{l}\text { multi continuous } \\
/ \text { discrete }\end{array}$ & $u$ & $\begin{array}{l}\text { asymmetric } \\
\text { continuous }\end{array}$ & yes & imperfect \\
$-[\overline{7}]$ & $\mathrm{n}$ & single discrete & $\succsim$ & $\begin{array}{l}\text { asymmetric } \\
\text { successive }\end{array}$ & no & imperfect \\
$-[\overline{8}]$ & 2 & single discrete & $\succsim$ & $\begin{array}{l}\text { asymmetric } \\
\text { continuous }\end{array}$ & yes & imperfect \\
\hline$[10]$ & 2 & single discrete & $\succsim$ & $\begin{array}{l}\text { symmetric si- } \\
\text { multaneous }\end{array}$ & no & imperfect \\
\hline
\end{tabular}




\section{Demonstration}

We consider here two agents, Alice and Bob, which are paratroopers landed in an unknown maze. They aim at meeting as soon as possible, i.e minimizing the maximum number of steps for an agent to reach the meeting point. Both of them have a local perception of the environment. Each agent can perceive the walls of her current cell. Moreover, she knows her own location. Additionally, the agents are allowed to communicate in order to negotiate the meeting point. The meeting point can be re-negotiate during the exploration of the maze. The optimal solution for finding a meeting point requires the knowledge of the whole maze. Under this assumption, the agents can compute the shortest path between them and set the meeting point in the middle of it. By contrast, a solution which does not need any prior knowledge consists of pseudo-randomly selecting a meeting point in the maze.

In order to illustrate this problem, we consider a $3 \times 3$ maze (cf Fig II) at the second step of the resolution. Each agent computes the distance to reach all the other cells based on her knowledge. For this purpose, an agent takes into consideration the perceived walls and she assumes that there is no wall between the cells she did not visit yet. In other words, the computation is performed by an A-star algorithm where the future path-cost function is the Manhattan distance. Since we want to minimize the maximum number of steps for an agent to reach the meeting point, the cell with the red flag is a good candidate. In order to solve this distributed solving problem, we use the negotiation protocol and strategy of [10] which allow to reach a fair solution.

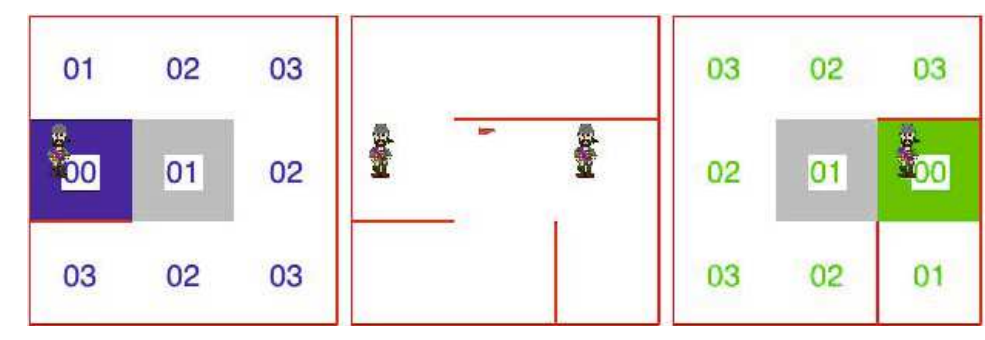

Fig. 1. The maze (at middle) and its internal representation for Alice (at left) and Bob (at right) at time $t=2$. In the latters, the visited cells are in grey, some walls may be still unknown and each cell is labelled with an estimation of the shortest path length.

Our demonstration exhibits the behaviours of agents exploring several mazes. These behaviours are the result of iterated negotiation games that take into account the information gathered by the agents during the exploration.

\section{Conclusion}

In this demonstration, we have illustrated a negotiation protocol which allows agents to make more than two offers per round and a negotiation strategy based 
on large (and eventually partial) preferences which does not assume that agents know the preferences of each other. In this way, we have demonstrated a fair negotiation process which does not give priority to one agent and which minimizes the maximum effort of one agent. We have applied our framework for distributed problem solving. In particular, we have considered the case of two agents in a maze which aims at negotiating a meeting in order to reach it as soon as possible. The path between the agents emerges from the repeated negotiations.

We are currently extending our bilateral negotiation game to a multi-party negotiation game where more than two agents play and observe moves.

\section{References}

1. Rosenschein, J., Zlotkin, G.: Rules of Encounter - Designing Conventions for Automated Negotiation among Computers. MIT Press (1994)

2. Rubinstein, A.: Perfect equilibrium in a bargaining model. Econometrica 50(1), 97-102 (1982)

3. Fatima, S.S., Wooldridge, M., Jennings, N.R.: Multi-issue negotiation with deadlines. Journal of Artificial Intelligence Research 27, 381-417 (2006)

4. Gatti, N., Giunta, F.D., Marino, S.: Alternating-offers bargaining with one-sided uncertain deadlines: an efficient algorithm. Artificial Intelligence 172(8-9), 1119$1157(2008)$

5. Sandholm, T., Vulkan, N.: Bargaining with deadlines. In: Proc. of AAAI, pp. 44-51 (1999)

6. Faratin, P., Sierra, C., Jennings, N.R.: Negotiation decision functions for autonomous agents. Robotics and Autonomous Systems 24(3-4), 159-182 (1998)

7. Morge, M., Picard, G.: Privacy-preserving strategy for negotiating stable, equitable and optimal matchings. In: Demazeau, Y., Pěchoucěk, M., Corchado, J.M., Pérez, J.B. (eds.) Adv. on Prac. Appl. of Agents and Multi. Sys. AISC, pp. 97-102. Springer, Heidelberg (2011)

8. Aydoğan, R., Baarslag, T., Hindriks, K.V., Jonker, C.M., Yolum, P.: Heuristicbased approaches for CP-nets in negotiation. In: Ito, T., Zhang, M., Robu, V., Matsuo, T. (eds.) Complex Automated Negotiations. SCI, vol. 435, pp. 115-126. Springer, Heidelberg (2012)

9. Jennings, N., Faratin, P., Lomuscio, A., Parsons, S., Wooldridge, M., Sierra, C.: Automated negotiation: Prospects methods and challenges. Group Decision and Negotiation 10(2), 199-215 (2001)

10. Delecroix, F., Morge, M., Routier, J.C.: Bilateral negotiation of a meeting point in a maze. In: Demazeau, Y., Corchado, J.M., Zambonelli, F., Bajo, J. (eds.) PAAMS 2014. LNCS (LNAI), vol. 8473, pp. 86-97. Springer, Heidelberg (2014) 